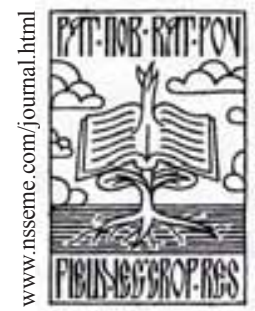

Soil and Crop Management / Gajenje i agrotehnika

Ratar. Povrt. / Field Veg. Crop Res. 48 (2011) 245-252

research note / prethodno saopštenje

\title{
Preliminary Results on Agronomic Performance of Barrel Medic (Medicago truncatula) in Serbia
}

\author{
Vojislav Mihailović · Aleksandar Mikić · Branko Ćupina · Dragan Milić · \\ Đorđe Krstić · Slobodan Katić · Sanja Vasiljević · Đura Karagić
}

\begin{abstract}
received / primljeno: 29.11.2010. revised / prerađeno: 27.12.2010. accepted / prihvaćeno: 30.12.2010.
\end{abstract} (C) 2011 IFVC

\begin{abstract}
Summary: A small-plot trial with eight Australian barrel medic (Medicago truncatula Gaertn.) cultivars was carried out in 2010 at Rimski Šančevi. The average green forage and forage dry matter yields were highest in Jemalong (30.7 tha $\mathrm{th}^{-1}$ and $\left.7.3 \mathrm{tha}^{-1}\right)$ and Parabinga $\left(30.7 \mathrm{tha}^{-1}\right.$ and $\left.8.0 \mathrm{t} \mathrm{ha}^{-1}\right)$. Forage dry matter crude protein content ranged between $150.8 \mathrm{~g} \mathrm{~kg}^{-1}$ in Parabinga and $179.4 \mathrm{~g} \mathrm{~kg}^{-1}$ in Jester. Forage neutral detergent fibre content varied from $305.2 \mathrm{~g} \mathrm{~kg}^{-1}$ in Sephi to $458.8 \mathrm{~g} \mathrm{~kg}^{-1}$ in Caliph, while the average forage acid detergent fibre content was $312.8 \mathrm{~g} \mathrm{~kg}^{-1}$. The average seed yield for all cultivars was $281 \mathrm{~kg} \mathrm{ha}^{-1}$ and may be considered satisfying, as it was obtained in a very rainy and warm growing season. Jemalong and Parabinga had the highest aboveground nitrogen yield (190 kg ha-1 and $\left.193 \mathrm{~kg} \mathrm{ha}^{-1}\right)$ and thus the greatest potential for green manure.
\end{abstract}

Key words: acid detergent fibre, barrel medic, forage crude protein yield, forage quality, forage yield, green manure, Medicago truncatula, model legume, neutral detergent fibre, seed yield

\section{Introduction}

The most important forage field legumes in Serbia are lucerne (Medicago sativa L.), red clover (Trifolium pratense L.), pea (Pisum sativum L.) and vetches (Vicia spp.). It is estimated that the cultivation area of lucerne varies between 180,000 ha and 200,000 ha, while red clover takes from 80,000 ha to 120,000 ha (Karagić et al. 2010). Lucerne is dominant in the northern parts of the country with rich chernozem soils, while red clover is more widely distributed in central Serbia, being more tolerant to prevailing acid soils. Pea and vetches are the most significant annual forage legumes, appreciated for the diversity of their use, ranging from green forage, forage dry matter and forage meal, over silage and haylage to dry grain and straw (Mikić et al. 2010a). Field pea (comprising forage and dry pea) is grown on about 25,000 ha in Serbia today, while vetches are grown on 7,500 ha (Mihailović et al. 2005).

V. Mihailović · A. Mikić $(\bowtie) \cdot$ D. Milić · S. Katić $\cdot$ S. Vasiljević · Đ Karagić

Institute of Field and Vegetable Crops, Maksima Gorkog 30, 21000 Novi Sad, Serbia

e-mail: aleksandar.mikic@ifvens.ns.ac.rs

B. Ćupina $\cdot$ Đ. Krstić

Faculty of Agriculture, University of Novi Sad, Trg Dositeja Obradovića 8, 21000 Novi Sad, Serbia
Barrel medic (Medicago truncatula Gaertn.) originated in the Mediterranean basin (Rubiales et al. 2009) and became widely naturalised in other regions of the world such as Australia, where annual medics are used as forages and soil improvers on about 50 million ha (Crawford et al. 1989). During the last decade of the last century, barrel medic was recognised as appropriate to be a model species for legumes, especially due to its diploid and small (about $510^{8}$ base pairs) genome, its self-fertile nature, its prolific seed production and its rapid generation time (Cook 1999, Young et al. 2003, Tivoli et al. 2008, Thompson et al. 2009). This was confirmed by various researches revealing a high synteny, i.e. an extensive conservation of gene order, not only between barrel medic and lucerne (Choi et al. 2004), but also between barrel medic and pea (Kaló et al. 2004). In this way, efforts in genomic research of barrel medic give new perspectives for lucerne breeding (Annicchiarico \& Scotti 2009, Julier \& Meusnier 2010). The oldest and largest collection of barrel medic is housed at the South Australian

\footnotetext{
Acknowledgements: This research was supported by the Ministry of Science and Technological Development of the Republic of Serbia. The authors are grateful to Rade Matic and his colleagues from SARDI for kindly donating the barrel medic seed material for this research.
} 
Research and Development Institute (SARDI), with more than 5,000 accessions (Ellwood 2006).

The main goal of this very preliminary research was to assess the possibility of growing barrel medic for forage production in the prevailing agro-ecological conditions of northern Serbia. It was especially aimed at assessing the length of its growing season when cultivated for forage and thus the possibility to include it as a shortseason crop in prevailing cropping systems in Serbia, with potentially preceding autumn-sown brassicas and succeeding sorghum, Sudan grass or short-season maize. At the same time, this research was aimed at determining the potential of barrel medic for seed production in the conditions of Serbia, as well as its hypothetical use as green manure crop.

\section{Materials and Methods}

A small-plot trial was carried out in 2010 at the experimental field of the Institute of Field and Vegetable Crops at Rimski Šančevi, near Novi Sad, $45^{\circ} 20^{\prime} \mathrm{N}, 19^{\circ} 51^{\prime} \mathrm{E}$ and $84 \mathrm{~m}$ asl. It included eight barrel medic cultivars of Australian origin, namely Borung, Caliph, Jemalong, Jester, Mogul, Parabinga, Paraggio and Sephi, kindly provided by SARDI.

The trial was established on April 23. All eight cultivars were sown at a density of about 250 viable seeds $\mathrm{m}^{-2}$ (Walsh et al. 2001), a plot size of $1 \mathrm{~m}^{2}$, three replicates for forage production and one plot for seed production, a row spacing of $20 \mathrm{~cm}$ both within and between plots in order to reduce excessive growth of border rows of a plot. In fact, each cultivar was sown in seven rows, but only five inside the plot were taken into account, while two border rows were discarded. The dominant weather and soil conditions during the trial period at Rimski Šančevi in 2010 are given in Tables 1 and 2 .

All eight cultivars were cut in full bloom and while forming first pods, being a desirable balance between yield and quality in majority of annual forage legumes (Mihailović et al. 2008). Quantitative morphological characteristics, such as average stem length $(\mathrm{cm})$, number of stems $\left(\right.$ plant $\left.^{-1}\right)$, number of leaves $\left(\right.$ plant $\left.^{-1}\right)$, number of flowers (plant ${ }^{-1}$ ) and number of leaves $\left(\right.$ plant $^{-1}$ ) were measured on the plant samples taken before the cutting. The plant samples of 30 plants per replication were taken from the middle rows of each plot. The same samples were used to measure the proportion of each plant part, namely stems, leaves, flowers and pods, in the total green forage yield and, after they were dried at the room temperature to a constant mass, in the total dry forage matter yield. Green forage yield $\left(t \mathrm{ha}^{-1}\right)$ was calculated on the basis of the green forage yield $\left(\mathrm{kg} \mathrm{m}^{-2}\right)$, measured immediately after

Table 1. Weather conditions during the trial with barrel medic at Rimski Šančevi in 2010

Tabela 1. Vremenski uslovi tokom ogleda sa buretastom lucerkom na Rimskim Šančevima 2010. godine

\begin{tabular}{|c|c|c|c|c|c|c|}
\hline $\begin{array}{l}\text { Month / Mesec } \\
\text { Year / Godina }\end{array}$ & $\begin{array}{l}\text { April / } \\
\text { April }\end{array}$ & $\begin{array}{l}\text { May / } \\
\text { Maj }\end{array}$ & $\begin{array}{l}\text { June / } \\
\text { Jun }\end{array}$ & $\begin{array}{l}\text { July / } \\
\text { Jul }\end{array}$ & $\begin{array}{c}\text { August / } \\
\text { Avgust }\end{array}$ & $\begin{array}{l}\text { Average / Sum } \\
\text { Prosek / Suma }\end{array}$ \\
\hline \multicolumn{7}{|c|}{ Average monthly temperature $\left({ }^{\circ} \mathrm{C}\right) /$ Srednja mesečna temperatura } \\
\hline 2010 & 13 & 17 & 20 & 23 & 22 & 19.0 \\
\hline $\begin{array}{l}\text { Long-term average } \\
\text { Višegodišnji prosek }\end{array}$ & 11 & 17 & 20 & 21 & 21 & 18.0 \\
\hline \multicolumn{7}{|c|}{ Monthly precipitation sum $(\mathrm{mm}) /$ Mesečna količina padavina } \\
\hline 2010 & 71 & 95 & 174 & 98 & 169 & 607 \\
\hline $\begin{array}{l}\text { Long-term average } \\
\text { Višegodišnji prosek }\end{array}$ & 47 & 59 & 85 & 70 & 59 & 320 \\
\hline
\end{tabular}

Table 2. Chemical properties of the surface chernozem soil layers during the trial with barrel medic at Rimski Šančevi in 2010

Tabela 2. Hemijske osobine površinskog sloja zemljišta tipa černozem tokom ogleda sa buretastom lucerkom na Rimskim Šančevima 2010. godine

\begin{tabular}{lccccccc}
\hline $\begin{array}{l}\text { Depth } \\
(\mathrm{cm})\end{array}$ & $\begin{array}{c}\mathrm{pH} \\
\text { Dubina }\end{array}$ & $\begin{array}{c}\mathrm{pH} \\
\mathrm{HCl}\end{array}$ & $\begin{array}{c}\mathrm{CaCO}_{2} \mathrm{O} \\
(\%)\end{array}$ & $\begin{array}{c}\text { Humus } \\
(\%)\end{array}$ & $\begin{array}{c}\mathrm{N} \text { total } \\
(\%) \\
\text { Ukupni } \mathrm{N}\end{array}$ & $\begin{array}{c}\mathrm{Al}-\mathrm{P}_{2} \mathrm{O}_{5} \\
\left(\mathrm{mg} 100 \mathrm{~g}^{-1}\right)\end{array}$ & $\begin{array}{c}\mathrm{Al}-\mathrm{K}_{2} \mathrm{O} \\
\left(\mathrm{mg} 100 \mathrm{~g}^{-1}\right)\end{array}$ \\
\hline $0-30$ & 7.41 & 7.90 & 5.61 & 2.97 & 0.196 & 17.99 & 21.00 \\
$30-60$ & 7.50 & 7.95 & 7.52 & 2.05 & 0.185 & 13.45 & 18.23 \\
\hline
\end{tabular}


the cutting, while forage dry matter yield $\left(t h a^{-1}\right)$ was calculated from plot fresh yield and forage moisture of the forage samples.

The chemical analysis of the forage dry matter in all eight cultivars included crude protein content $\left(\mathrm{g} \mathrm{kg}^{-1}\right)$, by multiplying the forage dry matter nitrogen content $\left(\mathrm{g} \mathrm{kg}^{-1}\right)$ by 6.25 , and the content $\left(\mathrm{g} \mathrm{kg}^{-1}\right)$ of neutral detergent fibre (NDF), acid detergent fibre (ADF) and lignin. Forage crude protein yield $\left(\mathrm{kg} \mathrm{ha}^{-1}\right)$ was calculated on the basis of the forage dry matter crude protein content and forage dry matter yield.

In the stage of full maturity of the seeds in the first pods, all eight cultivars were harvested by hand. Seed yield $\left(\mathrm{kg} \mathrm{ha}^{-1}\right)$ was calculated on the basis of the seed yield $\left(\mathrm{g} \mathrm{m}^{-2}\right)$, at a moisture content of $14 \%$. Thousand seed weight $(\mathrm{g})$ and seed viability (\%) were determined by the samples of 100 seeds one month after the harvest of each cultivar. In order to enable a basic statistical analysis with one plot only, the separate samples were taken from three middle rows, with the seed yield of each recalculated for the statistical purposes.

On the basis of forage dry matter nitrogen content and forage dry matter yield, aboveground nitrogen yield $\left(\mathrm{kg} \mathrm{ha}^{-1}\right)$ was calculated in order to assess the potential of the tested barrel medic cultivars for green manure.

Number of days from sowing to cutting and number of days from sowing to harvest for each of eight cultivars were also recorded.

The results were processed by the method of analysis of variance (ANOVA) with the LSD test, using the MSTAT-C software.

\section{Results and Discussion}

\section{Weather and soil conditions}

The growing season of barrel medic at Rimski Šančevi was by $1{ }^{\circ} \mathrm{C}$ warmer in comparison to long-term average (Tab. 1). At the same time, five months of the barrel medic growing season at Rimski Šančevi were characterised by almost twice precipitation relative to long-term average.

The chernozem soil at Rimski Šančevi was well provided with basic mineral nutrients and humus, with a slight alkaline reaction (Tab. 2), and thus might be considered favourable for the barrel medic cultivation.

\section{Forage yield}

There were significant differences among the average values of number of days from sowing to cutting and quantitative morphological characteristics related to forage yield in eight tested barrel medic cultivars (Tab. 3). Number of days from sowing to cutting varied between 55 in Parabinga and 71 in Mogul, pointing that barrel medic has much shorter growing season for forage production in comparison to traditional annual forage legumes such as common vetch, where it varies between 88 days and 102 days (Mikić 2008). On average, stem length in barrel

Table 3. Number of days from sowing to cutting and quantitative morphological characteristics related to forage yield in barrel medic cultivars at Rimski Šančevi in 2010

Tabela 3. Broj dana od setve do kosidbe i kvantitativne morfološke osobine vezane za prinos krme sorti buretaste lucerke na Rimskim Šančevima 2010. godine

\begin{tabular}{|c|c|c|c|c|c|c|}
\hline $\begin{array}{l}\text { Cultivar / } \\
\text { Sorta }\end{array}$ & $\begin{array}{l}\text { Number of } \\
\text { days from } \\
\text { sowing to } \\
\text { cutting / } \\
\text { Broj dana } \\
\text { od setve do } \\
\text { kosidbe }\end{array}$ & $\begin{array}{l}\text { Average stem } \\
\text { length } \\
\left(\mathrm{cm} \mathrm{plant}^{-1}\right) / \\
\text { Prosečna } \\
\text { dužina } \\
\text { stabala po } \\
\text { bilici }\end{array}$ & $\begin{array}{l}\text { Number of } \\
\text { stems } \\
\left(\text { plant }^{-1}\right) / \\
\text { Broj stabala } \\
\text { po biljci }\end{array}$ & $\begin{array}{c}\text { Number of } \\
\text { leaves } \\
\left(\text { plant }^{-1}\right) / \\
\text { Broj listova } \\
\text { po biljci }\end{array}$ & $\begin{array}{l}\text { Number of } \\
\text { flowers } \\
\left(\text { plant }^{-1}\right) / \\
\text { Broj cvetova } \\
\text { po biljci }\end{array}$ & $\begin{array}{l}\text { Number of } \\
\text { pods } \\
\left.\text { (plant }^{-1}\right) / \\
\text { Broj mahuna } \\
\text { po biljci }\end{array}$ \\
\hline Borung & 60 & 50 & 3.1 & 122 & 23 & 9 \\
\hline Caliph & 58 & 45 & 4.9 & 90 & 16 & 32 \\
\hline Jemalong & 60 & 41 & 6.9 & 122 & 35 & 12 \\
\hline Jester & 62 & 38 & 4.0 & 120 & 14 & 6 \\
\hline Mogul & 71 & 45 & 7.1 & 110 & 15 & 5 \\
\hline Parabinga & 55 & 45 & 3.2 & 136 & 22 & 38 \\
\hline Paraggio & 70 & 30 & 2.2 & 56 & 10 & 7 \\
\hline Sephi & 62 & 29 & 3.6 & 50 & 9 & 5 \\
\hline $\begin{array}{l}\text { Average } \\
\text { Prosek }\end{array}$ & 62 & 40 & 4.3 & 101 & 18 & 14 \\
\hline$L S D_{0.05}$ & 2 & 4 & 2.8 & 29 & 8 & 10 \\
\hline
\end{tabular}


medic was $40 \mathrm{~cm}$, similar to plant height in the first cut of lucerne, especially in the year of establishment (Mikić et al. 2007). With the number of stems ranging from 2.2 plant $^{-1}$ in Paraggio to 7.1 plant $^{-1}$ in Mogul, the barrel medic cultivars, in average, were moderately prone to basal branching in comparison to other annual forage legumes such as largeflowered (Vicia grandiflora Scop.) and other vetches (Mikić et al. 2009). The highest number of leaves was in Parabinga (136 plant $\left.{ }^{-1}\right)$. The cultivars Caliph and Parabinga had greater number of pods ( 32 plant $^{-1}$ and 38 plant $^{-1}$ ) than flowers in cutting and as compared to other six cultivars, witnessing their earliness and a faster transition from flowering to pod forming.

The average green forage and forage dry matter yields were highest in Jemalong (30.7 t ha ${ }^{-1}$ and $7.3 \mathrm{t} \mathrm{ha}^{-1}$ respectively), and Parabinga (30.7 $\mathrm{t} \mathrm{ha}^{-1}$ and $8.0 \mathrm{t} \mathrm{ha}^{-1}$ respectively) (Tab. 4). The forage dry matter yield in most of the tested cultivars at Rimski Šančevi was within the limits barrel medic achieved in the upper Midwest of USA on Hubbard loamy sand, ranging from about $4.7 \mathrm{t} \mathrm{ha}^{-1}$ to $9.1 \mathrm{t} \mathrm{ha}^{-1}$ (Zhu et al. 1998). This confirms that barrel medic has the potential for producing high forage yields in temperate regions such as the north-central USA and the northern Balkans, as well as that it might be used when traditional forage supplies are inadequate (Zhu et al. 1996).

It is considered that a higher ratio between leaves and stems in lucerne is mainly associated with shorter and thinner main stems, as well as that it is modestly and inversely correlated with forage yield (Annicchiarico 2007). In all eight

Table 4. Parameters related to forage yield in barrel medic cultivars at Rimski Šančevi in 2010 Tabela 4. Veličine vezane za prinos krme sorti buretaste lucerke na Rimskim Šančevima 2010. godine

\begin{tabular}{|c|c|c|c|}
\hline $\begin{array}{l}\text { Cultivar / } \\
\text { Sorta }\end{array}$ & $\begin{array}{l}\text { Green forage yield } \\
\left(t \mathrm{tha}^{-1}\right) / \\
\text { Prinos zelene krme }\end{array}$ & $\begin{array}{c}\text { Forage dry matter yield } \\
\left(\mathrm{t} \mathrm{ha} \mathrm{h}^{-1}\right) / \\
\text { Prinos suve materije } \\
\text { krme }\end{array}$ & $\begin{array}{c}\text { Forage dry matter } \\
\text { proportion / } \\
\text { Udeo suve materije krme }\end{array}$ \\
\hline Borung & 28.1 & 5.9 & 0.21 \\
\hline Caliph & 26.2 & 6.6 & 0.25 \\
\hline Jemalong & 30.7 & 7.3 & 0.24 \\
\hline Jester & 22.5 & 4.9 & 0.22 \\
\hline Mogul & 29.3 & 5.9 & 0.20 \\
\hline Parabinga & 30.7 & 8.0 & 0.26 \\
\hline Paraggio & 11.8 & 3.1 & 0.26 \\
\hline Sephi & 11.4 & 2.7 & 0.24 \\
\hline Average / Prosek & 23.8 & 5.6 & 0.24 \\
\hline$L S D_{0.05}$ & 8.2 & 1.9 & 0.03 \\
\hline
\end{tabular}

Table 5. Proportion of stems, leaves, flowers and pods in forage yield in barrel medic cultivars at Rimski Šančevi in 2010

Tabela 5. Udeo stabala, listova, cvetova i mahuna u prinosu krme sorti buretaste lucerke na Rimskim Šančevima 2010. godine

\begin{tabular}{|c|c|c|c|c|c|c|c|c|}
\hline \multirow[b]{2}{*}{$\begin{array}{l}\text { Cultivar / } \\
\text { Sorta }\end{array}$} & \multicolumn{4}{|c|}{$\begin{array}{l}\text { Green forage yield } \\
\text { Prinos zelene krme }\end{array}$} & \multicolumn{4}{|c|}{$\begin{array}{l}\text { Forage dry matter yield } \\
\text { Prinos suve materije krme }\end{array}$} \\
\hline & $\begin{array}{c}\text { Proportion } \\
\text { of stems / } \\
\text { Udeo } \\
\text { stabala }\end{array}$ & $\begin{array}{c}\text { Proportion } \\
\text { of leaves } \\
\text { / Udeo } \\
\text { listova }\end{array}$ & $\begin{array}{c}\text { Proportion } \\
\text { of flowers } \\
\text { / Udeo } \\
\text { cvetova }\end{array}$ & $\begin{array}{c}\text { Proportion } \\
\text { of pods / } \\
\text { Udeo } \\
\text { mahuna }\end{array}$ & $\begin{array}{c}\text { Proportion } \\
\text { of stems / } \\
\text { Udeo } \\
\text { stabala }\end{array}$ & $\begin{array}{c}\text { Proportion } \\
\text { of leaves / } \\
\text { Udeo } \\
\text { listova }\end{array}$ & $\begin{array}{c}\text { Proportion } \\
\text { of flowers } \\
\text { / Udeo } \\
\text { cretova }\end{array}$ & $\begin{array}{c}\text { Proportion } \\
\text { of pods / } \\
\text { Udeo } \\
\text { mahuna }\end{array}$ \\
\hline Borung & 0.63 & 0.32 & 0.03 & 0.02 & 0.58 & 0.38 & 0.03 & 0.01 \\
\hline Caliph & 0.56 & 0.34 & 0.01 & 0.09 & 0.54 & 0.35 & 0.02 & 0.10 \\
\hline Jemalong & 0.49 & 0.43 & 0.04 & 0.04 & 0.49 & 0.42 & 0.04 & 0.04 \\
\hline Jester & 0.60 & 0.36 & 0.01 & 0.02 & 0.59 & 0.38 & 0.01 & 0.02 \\
\hline Mogul & 0.60 & 0.37 & 0.01 & 0.01 & 0.57 & 0.41 & 0.02 & 0.01 \\
\hline Parabinga & 0.52 & 0.34 & 0.04 & 0.10 & 0.51 & 0.35 & 0.01 & 0.13 \\
\hline Paraggio & 0.58 & 0.38 & 0.02 & 0.02 & 0.55 & 0.41 & 0.01 & 0.03 \\
\hline Sephi & 0.51 & 0.41 & 0.03 & 0.04 & 0.49 & 0.42 & 0.05 & 0.05 \\
\hline $\begin{array}{l}\text { Average / } \\
\text { Prosek }\end{array}$ & 0.56 & 0.37 & 0.02 & 0.05 & 0.54 & 0.39 & 0.02 & 0.05 \\
\hline
\end{tabular}


tested barrel medic cultivars, stems had higher proportion than leaves (Table 5). The smallest difference in the stems to leaves ratio in forage dry matter yield was in both Jemalong and Sephi (49 : 42). Caliph and Parabinga were the only cultivars where the joint proportion of flowers and pods was higher than $10 \%$.

\section{Forage quality}

Barrel medic is considered a valuable source of forage protein, especially in mixtures with grasses (Stout et al. 1997). The average forage dry matter crude protein content in eight tested barrel medic cultivars ranged between $150.8 \mathrm{~g}$ $\mathrm{kg}^{-1}$ in Parabinga and $179.4 \mathrm{~g} \mathrm{~kg}^{-1}$ in Jester (Tab. 6). This was lower in comparison to the values
The content of forage NDF in eight barrel medic cultivars varied between $305.2 \mathrm{~g} \mathrm{~kg}^{-1}$ in Sephi and $458.8 \mathrm{~g} \mathrm{~kg}^{-1}$ in Caliph and with an average value of $363.5 \mathrm{~g} \mathrm{~kg}^{-1}$. In this way, barrel medic had lower forage NDF content than lucerne, with an average value of $391 \mathrm{~g} \mathrm{~kg}^{-1}$ (Julier et al. 2000) and almost equal to an average seasonal value of $369.3 \mathrm{~g} \mathrm{~kg}^{-1}$ in red clover (Vasiljević et al. 2008). In a similar way, the average forage ADF content in eight barrel medic cultivars $\left(312.8 \mathrm{~g} \mathrm{~kg}^{-1}\right)$ was lower in comparison to that in lucerne cultivars in the same agro-ecological conditions, with a range from $374.4 \mathrm{~g} \mathrm{~kg}^{-1}$ to 395.2 $\mathrm{g} \mathrm{kg}^{-1}$ (Katić et al. 2008), but also higher than an average seasonal value of $289.1 \mathrm{~g} \mathrm{~kg}^{-1}$ in red clover (Vasiljević et al. 2009). Sephi had the lowest forage lignin content $\left(62.5 \mathrm{~g} \mathrm{~kg}^{-1}\right)$, while had the highest forage lignin content $\left(103.8 \mathrm{~g} \mathrm{~kg}^{-1}\right)$.

Table 6. Parameters related to forage dry matter chemical composition $\left(\mathrm{g} \mathrm{kg}^{-1}\right)$ and forage crude protein yield $\left(\mathrm{kg} \mathrm{ha}^{-1}\right)$ in barrel medic cultivars at Rimski Šančevi in 2010

Tabela 6. Veličine vezane za hemijski sastav suve materije $\mathrm{krme}\left(\mathrm{g} \mathrm{kg}^{-1}\right)$ i prinos sirovih proteina krme $\left(\mathrm{kg} \mathrm{ha}^{-1}\right)$ sorti buretaste lucerke na Rimskim Šančevima 2010. godine

\begin{tabular}{lccccc}
\hline Cultivar / & $\begin{array}{c}\text { Forage dry } \\
\text { matter crude } \\
\text { protein content } \\
\text { Sorta }\end{array}$ & $\begin{array}{c}\text { Forage crude } \\
\text { Sadržaj sirovih } \\
\text { proteina suve } \\
\text { materije krme }\end{array}$ & $\begin{array}{c}\text { Prinos sirovih } \\
\text { proteina krme } \\
\text { detergent fibre } \\
\text { content } \\
\text { Sadržaj } \\
\text { neutralno- } \\
\text { deterdžentskih } \\
\text { vlakana krme }\end{array}$ & $\begin{array}{c}\text { Forage acid } \\
\text { detergent fibre } \\
\text { content / } \\
\text { Sadržaj kiselo- } \\
\text { deterdženstkih } \\
\text { vlakana krme }\end{array}$ & $\begin{array}{c}\text { Forage lignin } \\
\text { content / } \\
\text { Sadržaj lignina } \\
\text { krme }\end{array}$ \\
\hline Borung & 165.7 & 985 & 370.5 & 327.7 & 78.9 \\
Caliph & 162.5 & 1079 & 458.8 & 359.6 & 78.1 \\
Jemalong & 162.6 & 1187 & 335.1 & 290.3 & 75.7 \\
Jester & 179.4 & 879 & 377.8 & 311.8 & 103.8 \\
Mogul & 159.8 & 950 & 340.6 & 309.1 & 87.3 \\
Parabinga & 150.8 & 1206 & 386.7 & 327.5 & 101.6 \\
Paraggio & 167.3 & 511 & 333.3 & 280.2 & 65.3 \\
Sephi & 174.7 & 473 & 305.2 & 296.5 & 62.5 \\
Average / & 165.4 & 909 & 363.5 & 312.8 & 81.6 \\
Prosek & 13.9 & 376 & 68.4 & 40.1 & 19.8 \\
LSD $_{0.05}$ & & & & &
\end{tabular}

of forage dry matter crude protein content in lucerne cultivars, with a variation from $177 \mathrm{~g} \mathrm{~kg}^{-1}$ to $194 \mathrm{~g} \mathrm{~kg}^{-1}$ (Katić et al. 2009), and could partially be explained by an excessively rainy barrel medic growing season in 2010. Paraggio and Sephi had significantly lower forage crude protein yield $\left(511 \mathrm{~kg} \mathrm{ha}^{-1}\right.$ and $473 \mathrm{~kg} \mathrm{ha}^{-1}$ ) than the rest of the tested barrel medic cultivars, led by Parabinga $\left(1,206 \mathrm{~kg} \mathrm{ha}{ }^{-1}\right)$. Due to the prevailing conditions during its growing period in 2010, barrel medic had a lower average forage crude protein yields in comparison to other annual forage legumes such as pea, with more than $1,500 \mathrm{~kg} \mathrm{ha}^{-1}$ (Mihailović et al. 2010).

\section{Seed yield}

The number of days from sowing to harvest in eight barrel medic cultivars varied between 90 in Jester and Parabinga and 106 in Mogul (Tab. 7), with a similar general trend as the number of days from sowing to cutting and confirming once again that barrel medic also has shorter growing season for seed production in comparison to the traditional Serbian annual forage legumes such as common vetch, where it varies between 116 days and 136 days (Mikić 2008). The average seed yield in the tested barrel medic cultivars was $281 \mathrm{~kg}$ ha $\mathrm{a}^{-1}$ and may be considered satisfying bearing in 
Table 7. Parameters related to seed yield in barrel medic cultivars at Rimski Šančevi in 2010 Tabela 7. Veličine vezane za prinos semena sorti buretaste lucerke na Rimskim Šančevima 2010. godine

\begin{tabular}{lcccc}
\hline Cultivar / Sorta & $\begin{array}{c}\text { Number of days } \\
\text { from sowing to } \\
\text { harvest / } \\
\text { Broj dana od setve } \\
\text { do žetve }\end{array}$ & $\begin{array}{c}\text { Seed yield }\left(\mathrm{kg} \mathrm{ha}^{-1}\right) \\
\text { / Prinos semena }\end{array}$ & $\begin{array}{c}\text { Thousand seed } \\
\text { weight }(\mathrm{g}) / \\
\text { Masa hiljadu } \\
\text { semena }\end{array}$ & $\begin{array}{c}\text { Seed viability } \\
\text { (\%) / Klijavost } \\
\text { semena }\end{array}$ \\
\hline Borung & 92 & 159 & 3.7 & 55 \\
Caliph & 92 & 217 & 3.9 & 79 \\
Jemalong & 90 & 228 & 3.8 & 57 \\
Jester & 92 & 338 & 3.6 & 81 \\
Mogul & 106 & 199 & 3.9 & 95 \\
Parabinga & 90 & 276 & 4.0 & 49 \\
Paraggio & 104 & 395 & 4.1 & 94 \\
Sephi & 94 & 432 & 3.9 & 52 \\
Average / Prosek & 95 & 281 & 3.9 & 70 \\
LSD $_{0.05}$ & 3 & 121 & 1.5 & 23 \\
\hline
\end{tabular}

mind extremely unfavourable conditions for seed production during its growing season in 2010 and the average lucerne seed yields in Serbia between $255 \mathrm{~kg} \mathrm{ha}^{-1}$ and $468 \mathrm{~kg} \mathrm{ha}^{-1}$ (Karagić et al. 2010). The average thousand seed weight in eight barrel medic cultivars ranged from $3.6 \mathrm{~g}$ in Jester to $4.1 \mathrm{~g}$ in Paraggio, remaining within the limits of the species (Frame 2010) and confirming that the seeds in all barrel medic cultivars reached their ordinary size. A large variation in the values of seed viability among the tested cultivars, from $49 \%$ in Parabinga to $95 \%$ in Mogul, witness the existence of hard seeds in certain cultivars, while it remains unexplained if it is a specific interaction of individual genotype with environment or a consequence of different proteomic processes during seed development in

Green manure

The cultivar Jester had the largest forage dry matter nitrogen content $\left(28.7 \mathrm{~g} \mathrm{~kg}^{-1}\right)$ while the cultivar Parabinga had the lowest forage dry matter nitrogen content $\left(24.1 \mathrm{~g} \mathrm{~kg}^{-1}\right)$ (Tab. 8). Paraggio and Sephi produced significantly lower aboveground nitrogen yield $\left(82 \mathrm{~kg} \mathrm{ha}^{-1}\right.$ and $76 \mathrm{~kg} \mathrm{ha}^{-1}$ ) than the remaining barrel medic cultivars, especially Jemalong $\left(190 \mathrm{~kg} \mathrm{ha}^{-1}\right)$ and Parabinga (193 kg ha-1). Other annual legumes, such as grass pea (Lathyrus sativus L.), had the aboveground nitrogen yield of about $340 \mathrm{~kg} \mathrm{ha}^{-1}$ in the same agro-ecological conditions (Mikić et al. 2010).

Table 8. Forage dry matter nitrogen content $\left(\mathrm{g} \mathrm{kg}^{-1}\right)$ and aboveground nitrogen yield $\left(\mathrm{kg} \mathrm{ha}^{-1}\right)$ in barrel medic cultivars at Rimski Šančevi in 2010

Tabela 8. Sadržaj azota suve materije krme $\left(\mathrm{g} \mathrm{kg}^{-1}\right)$ i prinos nadzemnog azota $\left(\mathrm{kg} \mathrm{ha}^{-1}\right)$ sorti buretaste lucerke na Rimskim Šančevima 2010. godine

\begin{tabular}{lcc}
\hline Cultivar / Sorta & $\begin{array}{c}\text { Forage dry matter nitrogen } \\
\text { content }\left(\mathrm{g} \mathrm{kg}^{-1}\right) / \\
\text { Sadržaj azota suve materije } \\
\text { krme }\end{array}$ & $\begin{array}{c}\text { Aboveground nitrogen yield } \\
\left(\mathrm{kg} \mathrm{ha}^{-1}\right) / \\
\text { Prinos nadzemnog azota }\end{array}$ \\
\hline Borung & 26.5 & 158 \\
Caliph & 26.0 & 173 \\
Jemalong & 26.0 & 190 \\
Jester & 28.7 & 141 \\
Mogul & 25.6 & 152 \\
Parabinga & 24.1 & 193 \\
Paraggio & 26.8 & 82 \\
Sephi & 28.0 & 76 \\
Average / Prosek & 26.5 & 145 \\
$L S D_{0.05}$ & 2.1 & 48 \\
\hline
\end{tabular}




\section{Conclusions}

Although preliminary, the results of this agronomic performance evaluation of barrel medic in Serbia show that it has a certain potential for forage production. It is noteworthy that, even in a rainy and a warm spring and summer of 2010, it achieved satisfying forage yields of good quality and, in several cases, reliable seed yields, both during a relatively brief growing season. In that way, barrel medic could find its place as a short-lived forage or green manure crop in diverse cropping systems with benefits for both animal husbandry and soil fertility. At the same time, its promising preliminary agronomic performance opens a possibility for the evaluation of the results of various genomic research in field trials on chernozem and other prevailing soil and weather conditions in Serbia. Another field trial season with barrel medic has already begun with establishing the evaluation of cold tolerance in the autumn 2010.

\section{References}

Annicchiarico P (2007): Inter- and intra-population genetic variation for leaf : stem ratio in landraces and varieties of lucerne. Grass Forage Sci. 62: 100-103

Annicchiarico P, Scotti C (2009): Some burning questions for lucerne breeders. Grain Legum. 51: 18-19

Choi H-K, Kim D, Uhm T, Limpens E, Lim H, Mun J-H, Kalo P, Varma Penmetsa R, Seres A, Kulikova O, Roe B A, Bisseling T, Kiss G B, Cook D R (2004): A sequence-based genetic map of Medicago truncatula and comparison of marker colinearity with $M$. sativa. Genet. 166: 1463-1502

Cook D R (1999): Medicago truncatula — a model in the making! Curr. Opin. Plant Biol. 2: 301-304

Crawford E J, Lake A W H, Boyce K G (1989): Breeding annual Medicago species for semi-arid conditions in southern Australia. Adv. Agron. 42: 399-437

Ellwood S R, D' Souza N K, Kamphuis L G, Burgess T I, Nair R M, Oliver R P (2006): SSR analysis of the Medicago truncatula SARDI core collection reveals substantial diversity and unusual genotype dispersal throughout the Mediterranean basin. Theor. Appl. Genet. 112: 977-983

Frame J (2010): Grassland Species Profiles [Online]. [1 p] Available at http://www.fao.org/ag/AGP/AGPC/doc/Gbase/ data/meditrunc.htm (cited 29 November 2010, verified 29 November 2010). FAO, Rome

Gallardo K, Le Signor C, Vandekerckhove J, Thompson R D, Burstin J (2003): Proteomics of Medicago truncatula seed development establishes the time frame of diverse metabolic processes related to reserve accumulation. Plant Physiol. 133: 664-682

Julier B, Meusnier I (2010): Alfalfa breeding benefits from genomics of Medicago truncatula. Ratar. Povrt. / Field Veg. Crop Res. 47: 395-402

Julier B, Huyghe C, Ecalle C (2000): Within- and among-cultivar genetic variation in alfalfa: Forage quality, morphology, and yield. Crop Sci. 40: 365-369

Kaló P, Seres A, Taylor S A, Jakab J, Kevei Z, Kereszt A, Endre G, Ellis T H N, Kiss G B (2004): Comparative mapping between Medicago sativa and Pisum sativum. Mol. Genet. Genomics 272: 235-246
Karagić Đ, Jevtić G, Terzić D (2010): Forage legumes seed production in Serbia. Biotechnol. Anim. Husb. 26 (special issue): 1: $133-148$

Katić S, Mihailović V, Milić D, Karagić Đ, Glamočić D, Jajić I (2008): Genetic and seasonal variations of fibre content in lucerne. Proceedings, XXVIIth EUCARPIA Symposium on Improvement of Fodder Crops and Amenity Grasses, Copenhagen, Denmark, 19-23 August 2007, 130-135

Katić S, Milić D, Karagić Đ, Vasiljević S, Glamočić D, Jajić I (2009): Variation of protein, cellulose and mineral contents of lucerne as influenced by cultivar and cut. Biotechnol. Anim. Husb. 25: 1189-1195

Mihailović V, Mikić A, Ćupina B, Erić P (2005): Field pea and vetches in Serbia and Montenegro. Grain Legum. 44: 25-26

Mihailović V, Mikić A, Vasiljević S, Katić S, Karagić Đ, Ćupina B (2008): Forage yields in urban populations of hairy vetch ( $\mathrm{V} i$ cia villosa Roth) from Serbia. Grassl. Sci. Eur. 13: 281-283

Mihailović V, Mikić A, Katić S, Karagić Đ, Milošević B (2010): Potential of field pea for forage and grain protein yields. Ratar. Povrt. / Field Veg. Crop Res. 47: 43-48

Mikić A (2008): Genetic variability of agronomic characteristics of common vetch (Vicia sativa L.). MSc thesis. Faculty of Agriculture, University of Novi Sad, Novi Sad, Serbia

Mikić A, Mihailović V, Ćupina B, Krstić Đ, Hauptvogel R, Drobná J, Antalíková G (2009): Forage yields in urban populations of large-flowered vetch (Vicia grandiflora Scop.) from Serbia. Grassl. Sci. Eur. 14: 421-424

Mikić A, Mihailović V, Ćupina B, Đorđević V, Stoddard F L (2010a): Introduction of novel legume crops in Serbia - White lupin (Lupinus albus). Field Veget. Crop. Res. 47: 21-26

Mikić A., Mihailović V, Cupina B, Đurić B, Krstić Đ, Vasić M, Vasiljević S, Karagić Đ, Đorđević V (2010b): Towards the re-introduction of grass pea (Lathyrus sativus) in the West Balkan Countries: The case of Serbia and Srpska (Bosnia and Herzegovina). Food Chem. Toxicol. (in press) doi:10.1016/j.fct.2010.07.052

Mikić V, Radović J, Vasiljević S, Milić D (2007): Correlations between agronomic characteristics of lucerne (Medicago sativa L.) genotypes as affected by cutting. Proceedings, XXVI EUCARPIA Fodder Crops and Amenity Grasses Section and XVI Medicago spp. Group Joint Meeting, Perugia, Italy, 3-7 September 2006, 172-175

Rubiales D, Fernández-Aparicio M, Moral A, Pujadas A (2009): Collection and conservation of Iberian Medicago spp. germplasm. Grain Legum. 53: 29

Stout D G, Brooke B, Hall J W, Thompson D J (1997): Forage yield and quality from intercropped barley, annual ryegrass and different annual legumes. Grass Forage Sci. 52: 298-308

Thompson R, Aubert G, Duc G, Gallardo K, Lesignor C (2009): Medicago truncatula as a model legume. Grain Legum. 53: 5

Tivoli B, Baranger A, Sivasithamparam K, Barbetti M J (2008): Annual Medicago: From a model crop challenged by a spectrum of necrotrophic pathogens to a model plant to explore the nature of disease resistance. Ann. Bot. 98: 1117-1128

Vasiljević S, Glamočić D, Jajić I, Ćupina B, Katić S, Milić D, Mikić A (2008): Fibre fraction of red clover (Trifolium pratense L.) at different harvest over two seasons. Grassl. Sci. Eur. 13: 510-512

Vasiljević S, Milić D, Mikić A (2009): Chemical attributes and quality improvement of forage legumes. Biotechnol. Anim. Husb. 25: 493-504

Walsh M J, Delaney R H, Groose R W, Krall J M (2001): Performance of annual medic species (Medicago spp.) in southeastern Wyoming. Agron. J. 93: 1249-1256

Young N, Mudge J, Ellis T (2003): Legume genomes: more than peas in a pod. Curr. Opin. Plant Biol. 6: 199-204

Zhu Y, Sheaffer C C, Barnes D K (1996): Forage yield and quality of six annual Medicago species in the north-central USA. Agron. J. 88: 955-960

Zhu Y, Sheaffer C C, Russelle M P, Vance C P (2008): Dry matter accumulation and dinitrogen fixation of annual Medicago species Agron. J. 90: 103-108 


\title{
Prvi rezultati gajenja buretaste lucerke (Medicago truncatula) u Srbiji
}

\author{
Vojislav Mihailović ${ }^{1}$ Aleksandar Mikić ${ }^{1}$ Branko Ćupina ${ }^{2} \cdot$ Dragan Milić $^{1} \cdot$ Đorđe Krstić $^{2}$ \\ - Slobodan Katić ${ }^{1}$ Sanja Vasiljević ${ }^{1}$ Đura Karagić ${ }^{1}$ \\ ${ }^{1}$ Institut za ratarstvo i povrtarstvo, Maksima Gorkog 30, 21000 Novi Sad, Srbija \\ ${ }^{2}$ Poljoprivredni fakultet Univerziteta u Novom Sadu, Trg Dositeja Obradovića 8, 21000 Novi Sad, Srbija
}

Izvod: Mikro-ogled sa osam australijskih sorti buretaste lucerke (Medicago truncatula Gaertn.) izveden je na Rimskim Šančevima 2010. Najveći prosečni prinos zelene krme i suve materije krme bio je kod sorti Jemalong $(30,7$ $\mathrm{t} \mathrm{ha}^{-1}$ i 7,3 $\left.\mathrm{t} \mathrm{ha}^{-1}\right)$ i Parabinga $\left(30,7 \mathrm{t} \mathrm{ha}^{-1}\right.$ i 8,0 $\left.\mathrm{t} \mathrm{ha}^{-1}\right)$. Sadržaj sirovih proteina suve materije krme kretao se između $150,8 \mathrm{~g} \mathrm{~kg}^{-1} \mathrm{kod}$ sorte Parabinga i 179,4 $\mathrm{g} \mathrm{kg}^{-1} \mathrm{kod}$ sorte Jester. Sadržaj neutralno-deterdžentskih vlakana (NDF) krme kretao se od 305,2 $\mathrm{g} \mathrm{kg}^{-1}$ kod sorte Sephi do 458,8 $\mathrm{g} \mathrm{kg}^{-1} \mathrm{kod}$ sorte Caliph, dok je prosečni sadržaj kiselodeterdžentskih vlakana (ADF) bio 312,8 $\mathrm{g} \mathrm{kg}^{-1}$. Prosečan prinos semena svih sorti iznosio je $281 \mathrm{~kg} \mathrm{ha}^{-1}$ i može se smatrati zaodovoljavajućim s obzirom na veoma kišoviti i topli vegetacioni period vrste. Sorte Jemalong i Parabinga ostvarile su najveći prinos nadzemnog azota $\left(190 \mathrm{~kg} \mathrm{ha}^{-1}\right.$ i $\left.193 \mathrm{~kg} \mathrm{ha}^{-1}\right)$ i time najveći potencijal za zelenišno đubrenje.

Ključne reči: buretasta lucerka, kiselo-deterdžentska vlakna, kvalitet krme, Medicago truncatula, model mahunarke, neutralno-deterdžentska vlakna, prinos krme, prinos semena, prinos sirovih proteina krme, zelenišno đubrenje 